\title{
LEAD AND COPPER CONTAMINATION IN SMALL ARMS FIRING RANGES
}

\author{
D. DERMATAS \\ N. MENOUNO \\ P. DUTKO \\ M. DADACHOV \\ P. ARIENTI \\ V. TSANEVA*
}

W. M. Keck Geoenvironmental Laboratory, Center for Environmental Systems, Stevens Institute of Technology, Castle Point on Hudson, Hoboken, NJ, 07030, USA

*to whom all correspondence should be addressed:

Fax: +201-216-8212

Received: $26 / 08 / 03$ Accepted: 02/03/04

\begin{abstract}
Firing range activities have been proven to adversely impact the environment. The main concern in small arms firing ranges (SAFRs) is the fate and transport of heavy metals from bullets and bullet fragments accumulating in soil with lead $(\mathrm{Pb})$ being the primary contaminant. Frequently however, bullets are jacketed with copper $(\mathrm{Cu})$. The presence of $\mathrm{Cu}$ results in an increased galvanic corrosion potential. This in turn may lead to elevated levels of $\mathrm{Pb}$ release and subsequent lead mobility. In this paper we investigate the presence of $\mathrm{Pb}$ and $\mathrm{Cu}$ in an attempt to identify any synergistic effects between $\mathrm{Pb}$ and $\mathrm{Cu}$ and to accurately establish the extent of contamination. Soil samples from an active 20-position firing range and from a former range located at Fort Irwin in the Mojave Desert were analyzed for total concentrations of the respective metals. Overall, the $\mathrm{Pb}$ and $\mathrm{Cu}$ concentration levels and their spatial distribution correlated well with the associated range activities. Most $\mathrm{Cu}$ and $\mathrm{Pb}$ contamination appeared to concentrate at the berm surface with contamination levels rapidly decreasing with depth. Metal concentrations were elevated in the immediate vicinity of the target area, but were somewhat lower in areas between target positions. The presence of $\mathrm{Cu}$ increases the solubility of $\mathrm{Pb}$ by increasing its corrosion potential. $\mathrm{Pb}$ corrosion results in the formation of hydrocerussite and cerussite, a $\mathrm{Pb}$ carbonates.
\end{abstract}

KEYWORDS: $\mathrm{Pb}, \mathrm{Cu}$, galvanic corrosion, bullets, hydrocerussite, cerussite.

\section{INTRODUCTION}

The general study area is located at Fort Irwin, the National Training Center (NTC) in the heart of the Mojave Desert, $56 \mathrm{~km}$ northeast of Barstow, California. The entire NTC reservation encompasses more than 642,000 acres (2600 $\mathrm{km}^{2}$ ) of training area. Broad valleys surrounded by rugged mountain peaks dominate the NTC topography. The climate and types of soils encountered are different from other studies contacted in small arms firing ranges (SAFRs) located in temperate climates. Besides the relatively high $\mathrm{pH}$ of the local soils, the area receives a small amount of rain each year (10$15 \mathrm{~cm}$ ) and the majority of it happens in flash flooding events that result in high surface runoff (horizontal migration) and only limited water infiltration to the soil. Moreover, strong gusty winds of up to 35 knots will occasionally create powerful sandstorms adding to the horizontal migration of soil and other particulates.

The SAFRs studied herein are Range 5 and Goldstone. Range 5 is an active 20-position zeroing single-berm range, currently used for 
training with M-16 high velocity rifles. The absence of large bullet fragments from the Range 5 berm is significant, and is related to the type of weapons (M-16) used as well as the type of soils in the impact area. That is, the extensive bullet fragmentation, which occurs upon bullet impact onto the berm, is mainly due to the very high velocity of impact and the berm soils' granular texture. The Goldstone SAFR has been abandoned since 1972 and consists of indigenous playa clayey soil. Goldstone has an array of triangular shaped berms that were constructed using material (playa soil) that comes from the foot of the berms. Goldstone, during its long operation was used as an anti-aircraft weapons test range during World War II and, more recently, as a rifle firing range. In Goldstone intact projectile fragments of both rifle and artillery $(40 \mathrm{~mm})$ rounds were observed. However, due to the age of this range, many of the projectiles have corroded and exist in smaller size fragments.

Over the years there have been many reports on the corrosion behavior of ferrous metals in soil. Much less is known about electrochemical dissolution of non-ferrous metals in soil. One corrosion problem of significant environmental importance, which has been overlooked in the past, is that of spent small arms ammunitions in soil environments. For several decades at military SAFRs, spent bullets have been accumulating in soils. A wide spectrum of soil types and weathering conditions is involved. The corrosion products of $\mathrm{Pb}$ bullets in soil environments consist primarily of hydrocerussite $\left(\mathrm{Pb}_{3}\left(\mathrm{CO}_{3}\right)_{2}(\mathrm{OH})_{2}\right)$ with small amounts of massicot $(\mathrm{PbO})$ and cerussite $\left(\mathrm{PbCO}_{3}\right)$. These precipitates are sparingly soluble, their solubility being controlled largely by the site-specific soil chemistry and atmospheric conditions to which they are exposed (Chen and Daroub, 2002). Typically, military bullets consist of a $\mathrm{Pb}$ alloy slug surrounded by a $\mathrm{Cu}$ alloy jacket. The bullet jacket alloy could be made of $\mathrm{Cu}(89-95 \%), \mathrm{Pb}$ (maximum \% weight present is 0.05 ), and Iron (Fe) (maximum \% weight present is 0.05 ) and Zinc (Zn) (5-11\%). Although not as harmful as $\mathrm{Pb}, \mathrm{Cu}$ is also considered a toxic metal. Therefore, the release of soluble and precipitated corrosion products into soil is a potential concern, especially since little information is available regarding the interaction of these two metals.

Metallic $\mathrm{Pb}$ from the fragmented bullets is subjected to wet and dry events in a desert environment. Rainwater will act as an electrolyte, stimulating electron exchange (electron flow) between two dissimilar metals, resulting in galvanic corrosion. The nature of the corrosion process of metallic $\mathrm{Pb}$ and the behavior of dissolved $\mathrm{Pb}$ is highly dependent on the microenvironment, actually in contact with the metallic surface. More specifically, galvanic corrosion in the presence of $\mathrm{Cu}$, may adversely affect $\mathrm{Pb}$ release into the environment (Bundy at al., 1996).

This paper examines the extent of $\mathrm{Pb}$ and $\mathrm{Cu}$ contamination at two different firing ranges at Fort Irwin, NTC. Aqueous "Pb-Cu" corrosion experiments were also conducted in order to obtain specific information concerning the interaction of $\mathrm{Pb}$ and $\mathrm{Cu}$. Since $\mathrm{Pb}$ has a significantly lower electrode potential (-0.126 V) than $\mathrm{Cu}(+0.337 \mathrm{~V})$, when these metals coexist they will be subject to galvanic corrosion (Fontana and Greene, 1978). Consequently, $\mathrm{Pb}$ dissolution maybe higher in the presence of $\mathrm{Cu}$, thus, creating more of an environmental concern (Bricka at al., 1998).

\section{MATERIALS AND METHODS}

Five distinct surface samples and two random interior samples were obtained from the large continuous berm (128 m long and $2 \mathrm{~m}$ high) at Range 5. Surface samples were also collected at the immediate location of target positions as well as in-between target positions. Three distinct surface samples and two random interior samples were taken from three different berms at Goldstone range (berms number 3, 7 and 13), which are smaller in size (7.62 m long and 1.5$2.0 \mathrm{~m}$ high) than the one sampled in Range 5. Finally, at both sites, sediment core samples were also recovered for the purpose of measuring the contamination levels as a function of depth.

The samples were digested by following EPA method 3050B for total metal concentrations. Following acid digestion, they were filtered and analyzed using a Varian Vista-MPX inductively coupled plasma-optical emission spectroscopy (ICP-OES). Blanks, replicates, spiked samples and a set of reference materials was digested with each batch of samples for quality control purposes. NIST-2710 and NIST-2711 of the National Research Council of Canada (NRCC) were used as standard reference materials (SRM). Lead particles as well as bullet fragments from the ranges were also studied using Nikon (SMZ-1000) optical and Zeiss scanning electron microscopy (SEM). 


\section{Pb-Cu CORROSION EXPERIMENT}

Aqueous corrosion laboratory experiments were carried out in order to examine the dissolution behavior of $\mathrm{Pb}$ in the presence of $\mathrm{Cu}$. Metallic sheet specimens of lead $(20 \mathrm{mmX} 20 \mathrm{mmX} 1 \mathrm{~mm}$ at $99.9 \%$ by weight of $\mathrm{Pb}$ ) and copper $(20 \mathrm{mmX} 40 \mathrm{mmX} 0.5 \mathrm{~mm}$ at $99.9 \%$ by weight of $\mathrm{Cu}$ ) were prepared and immersed in $70 \mathrm{ml}$ solutions of de-ionized (DI) water ( $\mathrm{pH}$ of 5.0) in an open $200 \mathrm{ml}$ beaker (Figure 1). Four separate experiments performed, two with the concurrent immersion of both $\mathrm{Pb}$ and $\mathrm{Cu}$ metallic sheet specimens (one of each), and two with the immersion of only a single $\mathrm{Pb}$ metallic sheet specimen. Prior to the experiment the metal specimens were weighed and the surfaces were cleaned to remove any oxide deposits. All weights were measured using electronic microbalances. $\mathrm{Cu}$ surfaces were cleaned using a $10 \%$ solution of $1 \mathrm{~N}$ HCL. Pb surfaces were cleaned using silicon carbide \#400 polishing paper. The test beakers containing the metal specimens and DI water were left undisturbed for 72 hours, and then gently stirred for five seconds. Next, the metal specimens were removed from solution and weighed. The $\mathrm{pH}$ of the leachate solution was measured, then the solution was acidified by adding $0.5 \mathrm{ml} \mathrm{HNO}_{3}$ and subsequently analyzed for total $\mathrm{Pb}$ by ICP-OES.

Overall, water will act as an electrolyte, stimulating electron exchange (electron flow) between two dissimilar metals, resulting in galvanic corrosion. Corrosion reactions occur due to a difference in the electrode potentials. This reaction is driven by the tendency to equilibrate the ionic concentration in both sides in the overall cell.

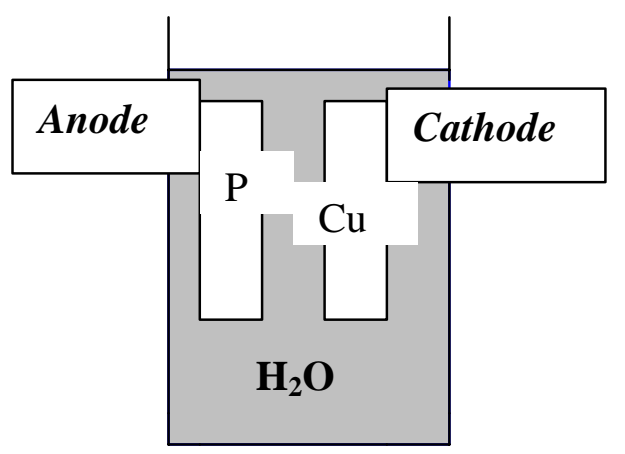

Figure 1. Pb-Cu corrosion experimental design.

Since $\mathrm{Pb}$ has a lower electrode potential than $\mathrm{Cu}$, it will supply electrons to the external circuit as it dissolves or corrodes. The anodic reaction can be given as:

$\mathrm{Pb} \rightarrow \mathrm{Pb}^{2+}+2 \mathrm{e}^{-}$(oxidation)

$\mathrm{E}^{0}=-0.126 \mathrm{~V}$ (anode)

Copper in that reaction will be the cathode. The cathodic reaction is equivalent to:

$\mathrm{Cu}^{2+}+2 \mathrm{e}^{-} \rightarrow \mathrm{Cu}$ (reduction)

$\mathrm{E}^{0}=+0.337 \mathrm{~V}$ (cathode)

For a galvanic cell, which operates spontaneously, a positive cell voltage will be obtained:

$\mathbf{E}$ cell $=\mathbf{E}$ cathode $-\mathbf{E}$ anode
or
$\mathbf{E}$ cell $=\mathrm{Cu}(+0.337 \mathrm{v})-\mathrm{Pb}(-0.126 \mathrm{v})=+0.463 \mathrm{v}$

Following the initiation of the corrosion process it is expected that the following chemical reactions will occur culminating with the formation of hydrocerussite and cerussite:

$\mathrm{Pb}+\mathrm{H}_{2} \mathrm{O} \rightarrow \mathrm{Pb}(\mathrm{OH})_{2}$

$\mathrm{Pb}(\mathrm{OH})_{2}+\mathrm{CO}_{2} \quad \rightarrow \quad \mathrm{Pb}_{3}\left(\mathrm{CO}_{3}\right)_{2}(\mathrm{OH})_{2}$

(Hydrocerussite)

$\mathrm{Pb}_{3}\left(\mathrm{CO}_{3}\right)_{2}(\mathrm{OH})_{2}+\mathrm{H}_{2} \mathrm{O}+\mathrm{CO}_{2} \rightarrow \mathrm{PbCO}_{3}$ (Cerussite)

\section{RESULTS AND DISCUSSIONS}

The soil $\mathrm{pH}$ was elevated in both ranges and is characterized as alkaline. In Range $5 \mathrm{pH}$ ranges from 8.03 to 8.30 and in Goldstone from 7.48 to 7.65 (Dermatas et al., 2002). Total $\mathrm{Pb}$ and $\mathrm{Cu}$ were found to occur over a broad range of concentrations. Total $\mathrm{Pb}$ concentrations ranged from 346 to $13587 \mathrm{mg} \mathrm{kg}^{-1}$ in the active range and from 43 to $2493 \mathrm{mg} \mathrm{kg}^{-1}$ in the abandoned range. In many cases, TCLP-Pb was higher than the U.S. Environmental Protection Agency (EPA) regulatory concentration level of $5 \mathrm{mg} \mathrm{l}^{-1}$ (Dermatas et al., 2002). Cu concentrations ranged from 19 to $347 \mathrm{mg} \mathrm{kg}^{-1}$ in Range 5 and from 38 to $312 \mathrm{mg} \mathrm{kg}^{-1}$ in Goldstone. California is one of the states where $\mathrm{Cu}$ is regulated. A close inspection of $\mathrm{Pb}$ and $\mathrm{Cu}$ concentrations for samples collected from Range 5 and Goldstone (Figure 2) indicates that the slope of the correlation curves between $\mathrm{Cu}$ and $\mathrm{Pb}$ concentrations is higher for Goldstone when 


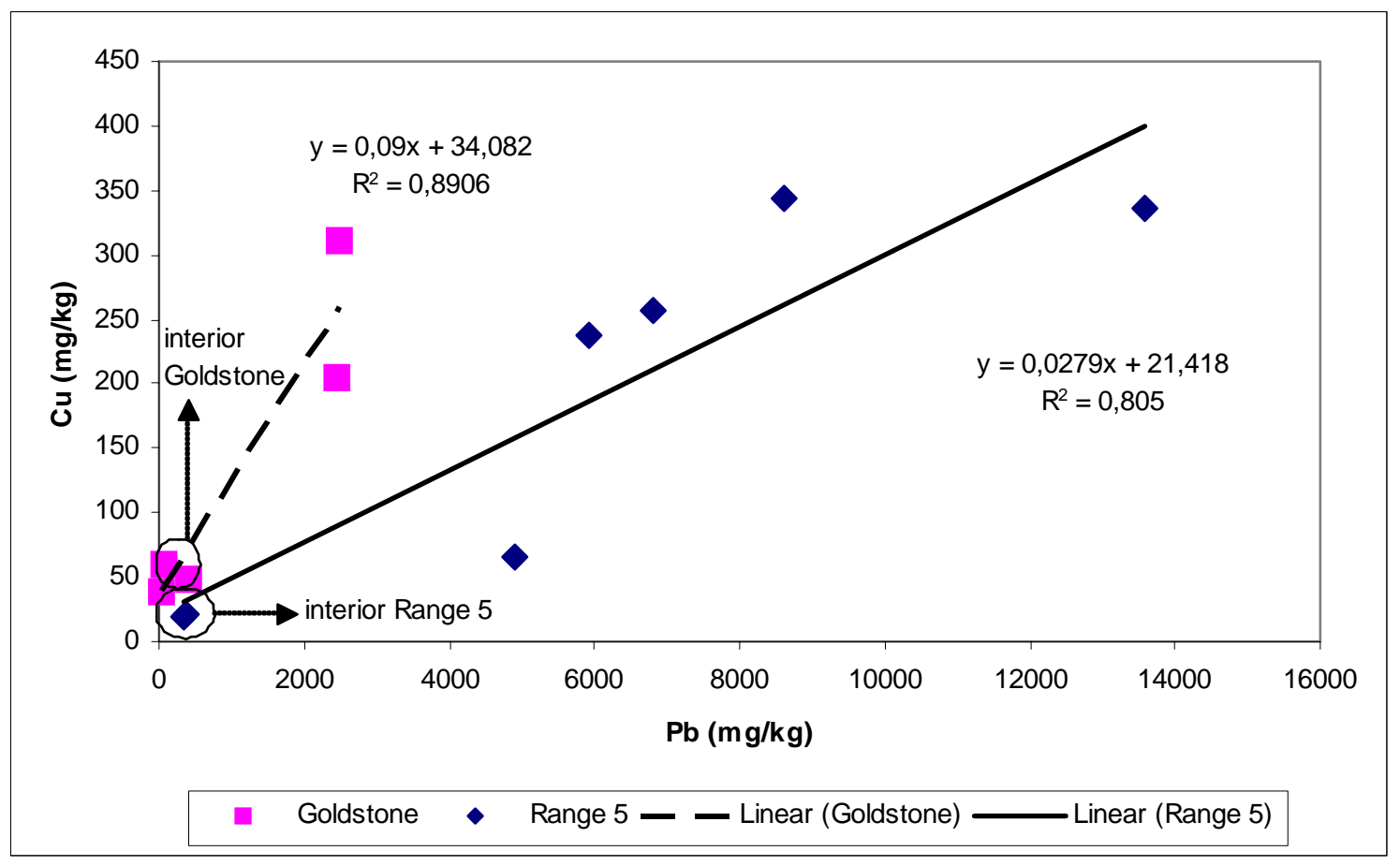

Figure 2. Correlation of $\mathrm{Cu}$ and $\mathrm{Pb}$ in soil samples from the berms of Range 5 and Goldstone ranges

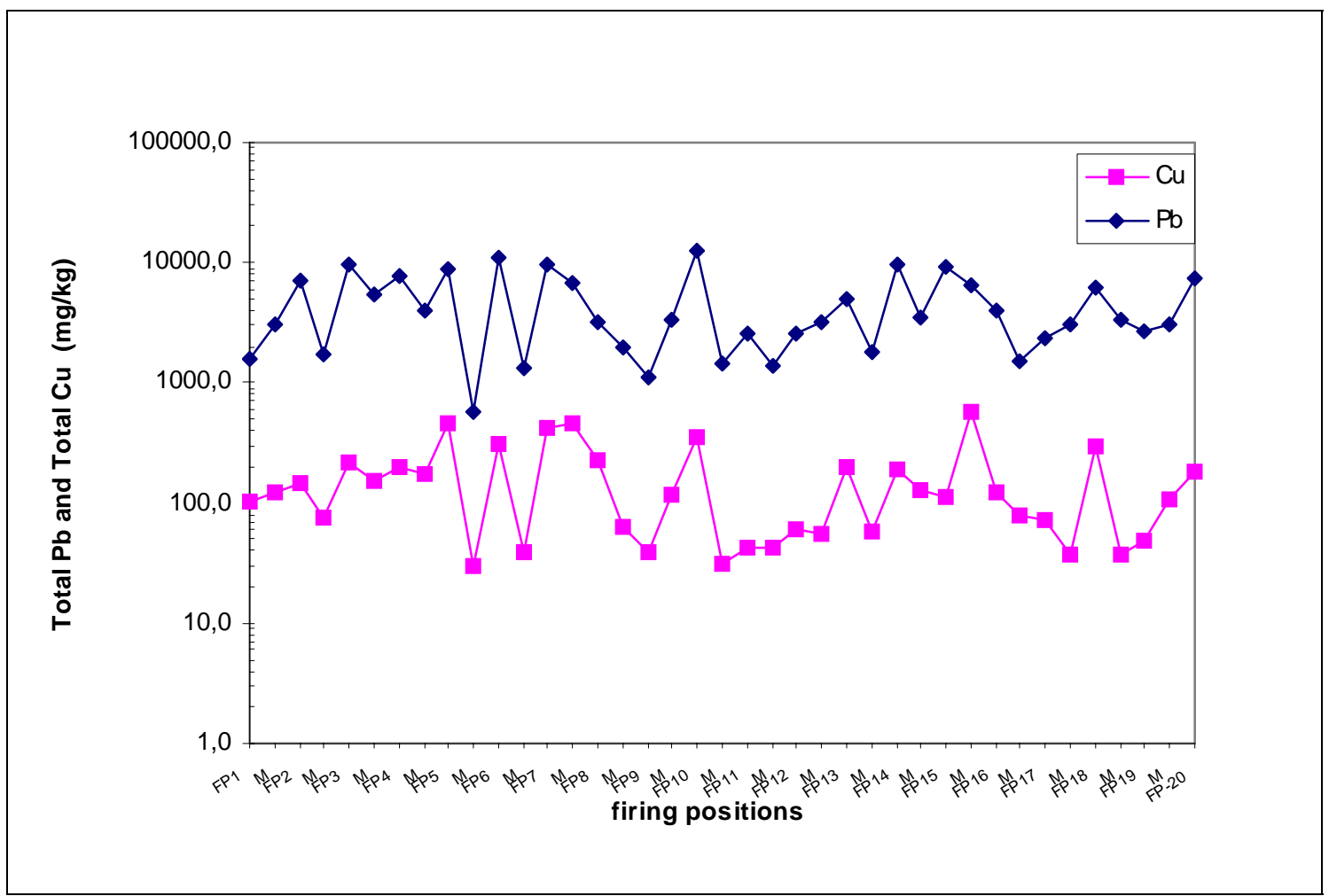

Figure 3. Distribution of $\mathrm{Pb}$ and $\mathrm{Cu}$ along the firing face of the berm at Range 5. Samples were taken in locations corresponding to the designated firing positions as well as in between firing positions from the surface of the berm 


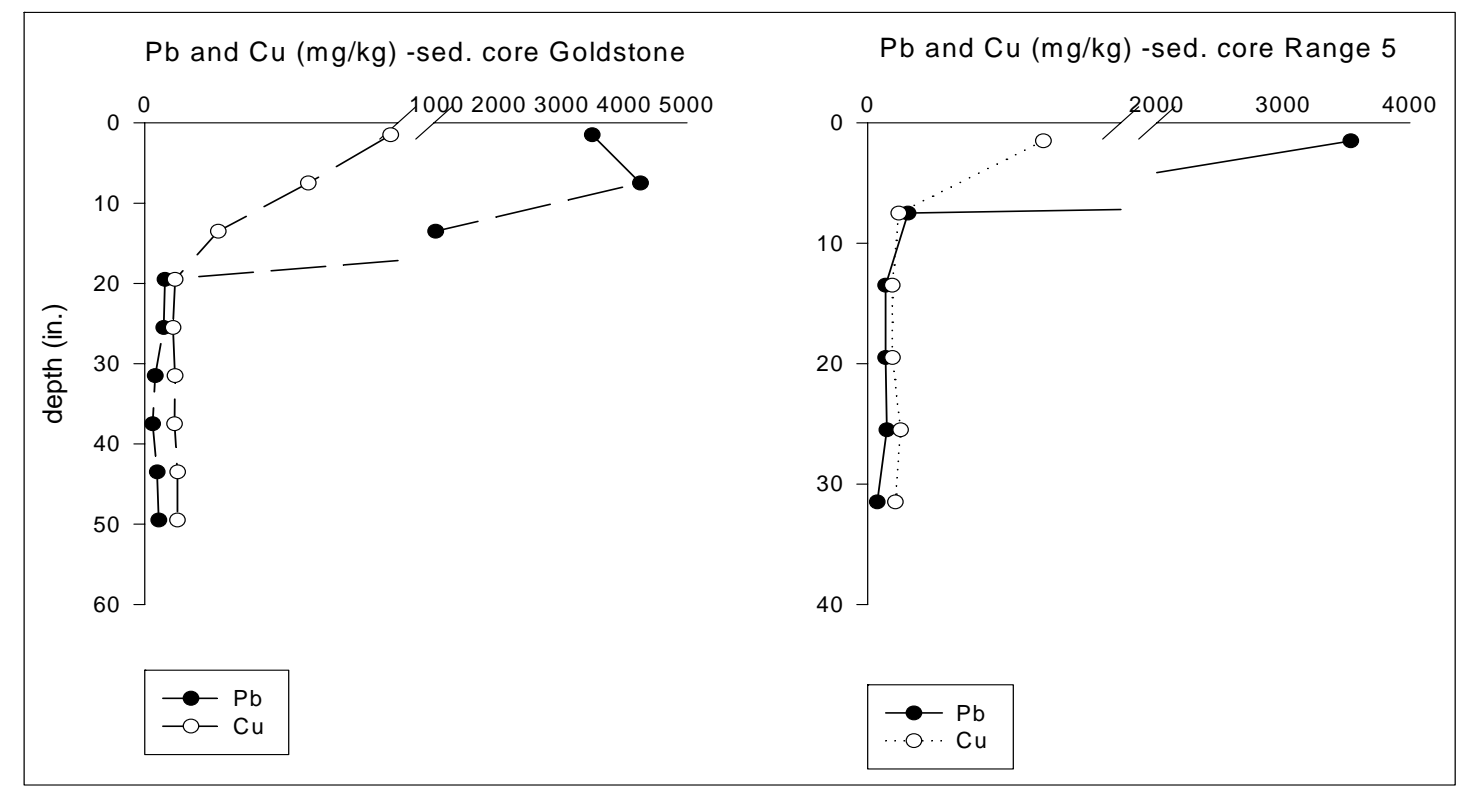

Figure 4. Sediment core samples total $\mathrm{Pb}$ and $\mathrm{Cu}$ concentration depth profiles from Goldstone and Range 5.

compared to Range 5. This can be explained by the fact that $\mathrm{Cu}$ concentrations are similar for both ranges, whereas $\mathrm{Pb}$ concentrations are significantly lower in the abandoned range. These differences imply that relative to $\mathrm{Cu}, \mathrm{Pb}$ depletion is higher in Goldstone than in Range 5 or that $\mathrm{Pb}$ loading is different (weapons fired, type of bullets, type of berm soil). The respective concentration correlations for both elements between ranges are shown in Figure 2 . Moreover, it seems that both $\mathrm{Pb}$ and $\mathrm{Cu}$ concentrations are drastically lower (by at least an order of magnitude) for the interior samples collected. This indicates a limited downward mobility for both metals, which can be explained by the limited rainfall and water infiltration into the soil, characteristic of desert climatic conditions. Overall, the generally higher $\mathrm{Pb}$ concentration levels observed for Range 5 can be at least partly explained by the respective range activities. In Range 5 high velocity M-16 rifle firing is directed at the same fixed target area along the face of the berm from fixed firing positions. In Goldstone, the type of use has varied significantly over the years resulting in a more widespread, less concentrated $\mathrm{Pb}$ contamination. Moreover, in Range 5, the high velocity bullets impact a berm composed of a highly angular granular soil. The result of impact is extensive bullet fragmentation, as confirmed by the absence of large bullet fragments in all soil samples collected. Conversely, at Goldstone the relatively lower velocity of bullet impact due to the type of weapons historically used and the fact that the impact medium is a clayey soil would have resulted in much more limited bullet fractionation upon impact. This was confirmed by the large quantity of intact projectile fragments and large bullet fragments of both rifle and artillery $(40 \mathrm{~mm})$ rounds encountered in most surface soil samples collected. Intact projectiles

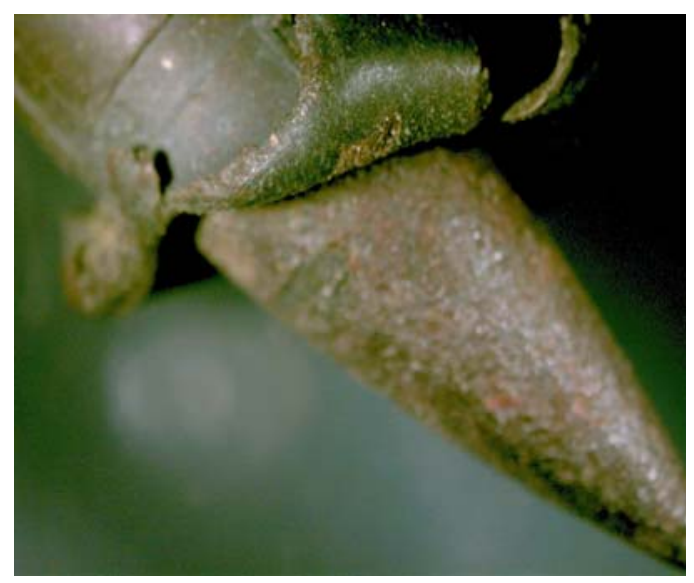

Figure 5. Optical photo of corroded bullet collected near Berm 3, Goldstone.

and large bullet fragments were separated and not included in the samples tested for total metals. Samples were also taken at the 
target positions and in-between target positions (target positions correspond to firing positions) at Range 5. Referring to the plot in Figure $3, \mathrm{~Pb}$ and $\mathrm{Cu}$ concentrations are elevated in the area directly behind the target but are lower in areas between targets. The $\mathrm{Pb}$ and $\mathrm{Cu}$ concentrations range from 600 to $13,000 \mathrm{mg} \mathrm{kg}^{-1}$ and from 30 to 600 $\mathrm{mg} \mathrm{kg}{ }^{-1}$ respectively. As can be seen in Figure 3 at Range 5 there is a strong correlation between the total $\mathrm{Pb}$ and $\mathrm{Cu}$ concentrations along the entire firing face of the berm. More specifically, the $\mathrm{Cu}$ concentration results mostly follow the same trend observed for the $\mathrm{Pb}$ data.

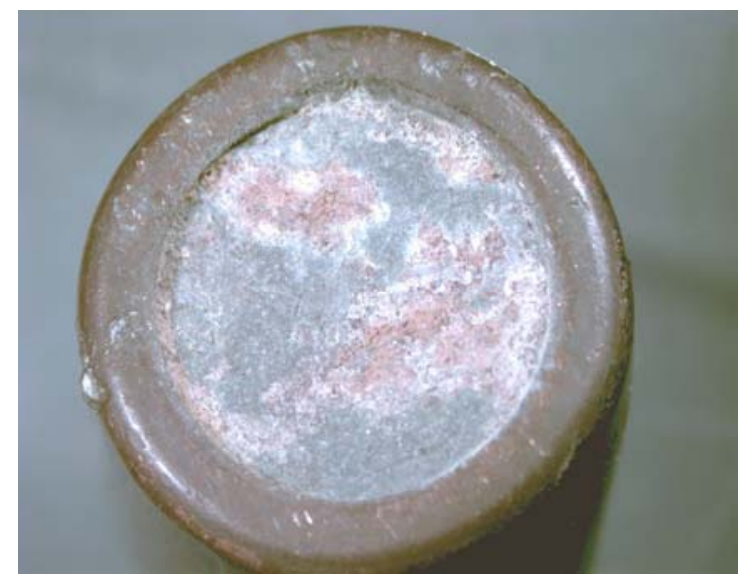

Figure 6. Optical photo of lead bullet recovered at Goldstone, showing corroded area and carbonized lead

Copper and $\mathrm{Pb}$ show similar patterns of downward mobility in the sediment core concentration plots shown in Figure 4 for both Range 5 and Goldstone. It generally appears that the mobility of both metals is significantly reduced within the first 20 inches $(\sim 50 \mathrm{~cm})$ in Goldstone and within the first 10 inches $(\sim 25 \mathrm{~cm})$ downward into the soil subsurface.

As it can be readily seen in Figures 5 and 6 spent copper-jacketed lead bullets collected at Goldstone show clear indications of corrosion. What is also significant to note, as illustrated in both Figures (5 and 6), is that $\mathrm{Pb}$ and $\mathrm{Cu}$ remain in close contact and have not been separated. Therefore, $\mathrm{Pb}-\mathrm{Cu}$ galvanic corrosion effects would also have to be considered. These were considered by performing the $\mathrm{Pb}-\mathrm{Cu}$ corrosion tests. The $\mathrm{Pb}-\mathrm{Cu}$ corrosion experiments showed that with both $\mathrm{Pb}$ and $\mathrm{Cu}$ present, $\mathrm{Pb}$ concentrations in solution were significantly higher than $\mathrm{Pb}$ concentrations with only $\mathrm{Pb}$ being present (Table 1). Moreover, our concentration results are confirmed by the more pronounced decrease in the final weight of metallic $\mathrm{Pb}$ (0.0229g for Sample 1 and 0.0237g for Sample 2 ) in the presence of metallic $\mathrm{Cu}$. Conversely, the weight of metallic $\mathrm{Pb}$ decreased by $0.0091 \mathrm{~g}$ for Sample 3 and 0.0088g for Sample 4 when $\mathrm{Cu}$ was not present. Overall, the $\mathrm{Pb}-\mathrm{Cu}$ corrosion experiments confirmed our hypothesis that $\mathrm{Pb}$ corrosion and subsequent dissolution would be more pronounced in the presence of $\mathrm{Cu}$ as compared with having only $\mathrm{Pb}$. In order to confirm the formation of hydrocerussite and cerussite, SEM examination of the lead surface was performed as discussed in the following paragraph.

The $\mathrm{Pb}$ specimen was observed under an electron microscope to obtain more detailed information regarding surface morphology. Scanning electron micrographs, (SEMs) were obtained by using a Zeiss Scanning Electron Microscope at two different magnifications (Figure $7 \mathrm{a}, \mathrm{b}$ ). Picture (a) represents cerussite crystals at $5000 \mathrm{x}$ magnification, formed as coating on the surface of metallic $\mathrm{Pb}$ during the $\mathrm{Pb}-\mathrm{Cu}$ corrosion experiment. Hydrocerussite crystals are clearly visible in picture (b) at 10000x magnification.

Hydrocerussite and cerussite are only sparingly soluble within the $\mathrm{pH}$ ranges encountered at both sites, and this may partly explain the limited $\mathrm{Pb}$ downward mobility observed in the analytical results presented previously.

\section{CONCLUSIONS}

In summary, present study results indicate that $\mathrm{Pb}$ and $\mathrm{Cu}$ concentration levels at the SAFRs studied are highly elevated at the surface but quickly decrease as a function of increasing depth from the ground surface. Samples that were randomly taken from the interior of the berms showed $\mathrm{Pb}$ and $\mathrm{Cu}$ concentrations that were one order of magnitude lower than concentrations in surface samples for both ranges. Moreover, sediment core analytical results showed that both $\mathrm{Pb}$ and $\mathrm{Cu}$ vertical migration is limited. This limited downward mobility is most likely due to the alkaline characteristics of the soil, $\mathrm{pH}$ range 7.48-7.65 for Goldstone range and 8.03-8.30 for Range 5. Within these $\mathrm{pH}$ ranges, secondary $\mathrm{Pb}$ mineral formations are relatively stable. However, because of flash flooding events and occasional sandstorms significant levels of horizontal migration can be expected. 
Table 1. Summary of experimental data from the $\mathrm{Pb}-\mathrm{Cu}$ corrosion experiments.

\begin{tabular}{|l|l|l|l|l|l|}
\hline & & Weight Pb & Weight Pb & $\begin{array}{l}\text { Pb Weight } \\
\text { loss }\end{array}$ & Pb \\
\hline ID & Sample & Initial (g) & Final (g) & $(\mathrm{g})$ & $\mathrm{mg} \mathrm{l}^{-1}$ \\
\hline 1 & $\mathrm{~Pb}+\mathrm{Cu}$ & 5,8739 & 5,8510 & 0,0229 & 328,5 \\
2 & $\mathrm{~Pb}+\mathrm{Cu}$ & 6,2078 & 6,1841 & 0,0237 & 345,4 \\
3 & $\mathrm{~Pb}$ & 6,1442 & 6,1351 & 0,0091 & 210,7 \\
4 & $\mathrm{~Pb}$ & 5,9589 & 5,9510 & 0,0088 & 182,2 \\
\hline
\end{tabular}

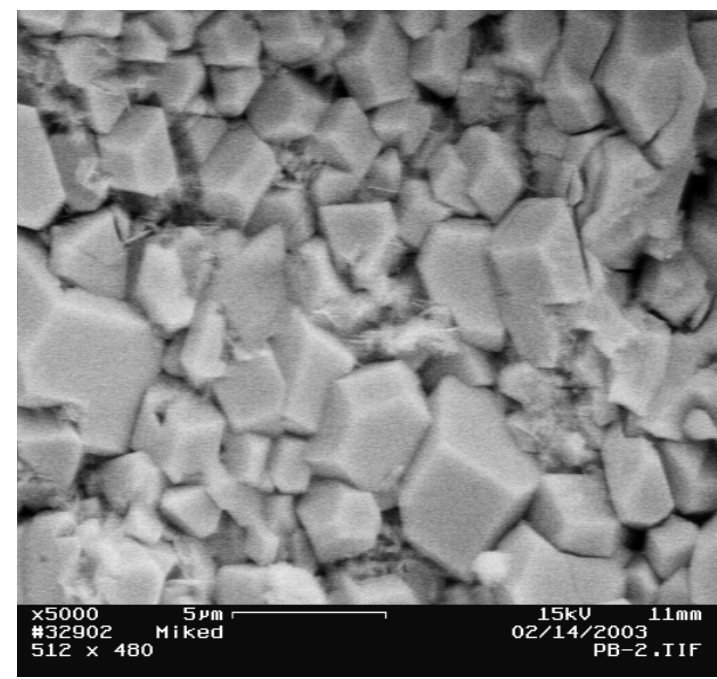

(a) $5000 x$

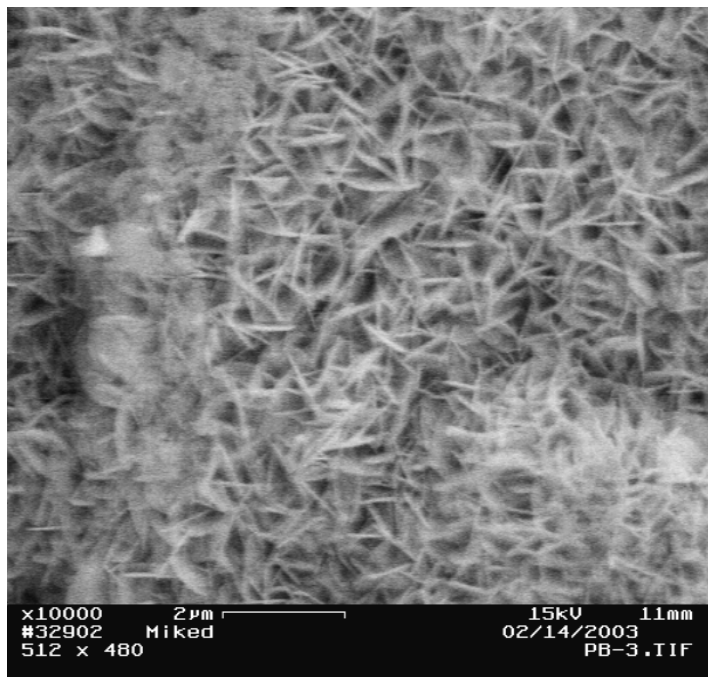

(b) $10000 \mathrm{x}$

Figure 7. Scanning electron micrographs of the surface of metallic Pb specimen at (a) 5000x and (b) 10000x magnifications.

Correlation between $\mathrm{Pb}$ and $\mathrm{Cu}$ concentrations for the two SAFR sites showed that $\mathrm{Pb}$ concentrations are lower in Goldstone than in Range 5, whereas $\mathrm{Cu}$ concentration levels seem to be similar. Moreover, surface sample metal concentrations observed along the berm face in Range 5, clearly indicate a strong correlation between $\mathrm{Pb}$ and $\mathrm{Cu}$ concentrations observed; $\mathrm{Cu}$ concentration results mostly follow the same trend observed for the $\mathrm{Pb}$ data. Metal concentrations measured also correlate well with the associated range activities. That is, $\mathrm{Pb}$ and $\mathrm{Cu}$ concentrations appear to be elevated at the direct area of the target but are significantly lower at the intermediate areas. Differences in range activities between Range 5 and Goldstone can also explain the relatively higher levels of $\mathrm{Pb}$ concentration observed in Range 5. Optical microscopy analyses showed that $\mathrm{Pb}$ and $\mathrm{Cu}$ coexist in large bullet fragments recovered from Goldstone and confirmed the galvanic corrosion hypothesis. In turn, $\mathrm{Pb}-\mathrm{Cu}$ corrosion experimental results indicated that the presence of $\mathrm{Cu}$ increases the solubility of $\mathrm{Pb}$ significantly, due to the galvanic corrosion reaction. Finally, the formation of cerussite as an immediate product of the $\mathrm{Pb}$ corrosion was confirmed by means of SEM analyses. The formation of secondary minerals such as hydrocerussite and cerussite explains the limited vertical mobility of $\mathrm{Pb}$ in these environments.

\section{REFERENCES}

Bricka R.M, Rivera Y.B. and Deliman P.N. (1998), Vertical Migration Potential of Metal Contaminants at Small Arms Firing Ranges, Camp Edwards Military Reservation, 
Massachusetts, Technical Report IRRP-98-3, U.S. Army Corps of Engineers Waterways Experiment Station, Vicksburg, MS.

Bundy K.J., Bricka M. and Morales A. (1996), An Electrochemical Approach for Investigations in Firing Ranges, In: Proceedings of the HSRC/WERC Joint Conference on the Environment, Albuquerque, NM.

Chen M. and Daroub S.H. (2002), Characterization of Lead in Soils of a Rifle/Pistol Shooting Range in Central Florida, Soil and Sediment Contamination Journal, 11, 1-17.

Dermatas D., Menounou N. and P. Dutko (2002), Lead contamination in small arms firing ranges, In: Proc. Restoration and Protection of the Environment VI, July 1-4, 2002, Skiathos Island, Greece.

Fontana M.G. and Greene N.D. (1978), Corrosion Engineering, 2nd ed., John Wiley \& Sons, Inc., New York. 